\title{
A Atividade Comercial e sua Relação com o Urbano: \\ o exemplo de Londrina
}

\section{The Commercial Activity and it's Relationship with the Urban: the Londrina Example}

\author{
Maria Luiza Fava Grassiottoํㅜ Junker de Assis Grassiotto ${ }^{2}$
}

Resumo

\begin{abstract}
A partir de princípios do século XX, a história narrativa foi substituída pela história problema. Desde então, existem diversos modos de se contar uma história. Nesse sentido, as cidades, seu crescimento e desenvolvimento podem ser vistos sob várias óticas. Este texto procura contar um pouco da história de Londrina, cidade média de aproximadamente 500.000 habitantes, sob o ângulo da atividade comercial e sua relação com o crescimento e desenvolvimento urbano. Iniciando com o relato da importância da atividade comercial na vida do homem e das cidades, remete-se à vocação comercial de Londrina, desde suas origens, comentando sua evolução e transformação gradativa até o aparecimento do shopping Center. Ao final, mostra o papel do shopping center, edifício símbolo do século XX, na atual configuração urbana e arquitetônica da cidade.
\end{abstract}

Palavras chave: Atividade comercial, shopping center, setor terciário, arquitetura comercial, atividade comercial e o urbano.

\begin{abstract}
Since the beginning of twentieth century, the narrative history has been substituted by the problem history; nowadays there are several ways to tell a story. In this sense, the cities, their growth and development can be analysed under different perspectives. This text tells a little about the history of Londrina, a city with 500,000 inhabitants, focussing on the commercial activity and its relation to urban growth and development. This text starts relating the importance of the commercial activity in the lives of the men and the cities. Then, it describes the commercial vocation of Londrina since its origin, dealing with its evolution and gradual trasnsformation until the establishment of the Shopping Center. Finally, it shows the role of the shopping center, a twentieth century symbol, in the current urban and architectural configuration.
\end{abstract}

Key words: Commercial activity, shopping center, tertiary sector, commercial architecture, the commercial and urban activity.

\footnotetext{
${ }^{1}$ Arquiteta, professora e pesquisadora da UEL, Mestre em Arquitetura e Urbanismo pelo MINTER FAU/USP - DAU/UEL, pesquisadora do NUTAU (Núcleo de Tecnologia em Arquitetura e Urbanismo da FAU/USP), doutoranda pela FAU/USP). Email: grassiotto@uel.br.

2 Engenheiro civil, Mestre em Arquitetura e Urbanismo pelo MINTER FAU/USP - DAU/UEL, professor da Universidade Norte do Paraná - UNOPAR, pesquisador da UEL, pesquisador do NUTAU (Núcleo de Tecnologia em Arquitetura e Urbanismo FAU/ USP), doutorando pela FAU/USP. E-mail: junker.grassiotto@ prof.unopar.br.
} 


\section{Os Modos de Olhar}

$\mathrm{Na}$ antigüidade a história apresentava-se sob diversos gêneros: como crônica monástica, memória política, tratado de antiquários, e outros. Mas, predominantemente, era contada através de acontecimentos políticos e feitos de chefes militares e reis. No século XVIII surgiram contestações com relação a essa prática, se almejava uma "história da sociedade", onde as principais preocupações fossem seus costumes, moral, leis e o comércio. No início do século XX, um grupo chamado Escola dos Annales conseguiu fazer uma "nova história", abrindo os limites da historiografia tradicional, buscando em outras ciências, conceitos e instrumentos atuantes na visão do historiador. A história narrativa foi substituída por uma história problema; esta passou a compreender todas as atividades humanas e não apenas a política; e a colaboração de disciplinas como geografia, sociologia, psicologia, e outras, passou a ser comum (BURKE, 1991).

A partir desse raciocínio, atualmente há diversos modos de se contar a história de uma cidade. Seu crescimento e desenvolvimento podem ser vistos sob várias óticas. Muitos são os trabalhos que abordam a cidade em relação a: sua origem, colonização e população; aspectos físicos, topográficos, climáticos e geográficos; situação da agricultura; transporte e comunicação; desenvolvimento econômico, social e político; e outros. Gunn (2002), discute a evolução da cidade de São Paulo de um modo singular, através dos Saberes Profissionais: a Cidade dos Advogados e dos Juizes; a Cidade dos Médicos; a Cidade dos Sanitaristas; a Cidade dos Engenheiros; os projetos de embelezamento; a Cidade dos Religiosos e sua preocupação social; e assim por diante.

Este texto procura contar um pouco da história de Londrina, cidade média de aproximadamente 500.000 habitantes, sob o ângulo da atividade comercial e sua relação com o crescimento e desenvolvimento urbano. Remete-se à vocação comercial da cidade, desde suas origens, aborda sua evolução e transformação gradativa até o aparecimento do shopping center. Ao final, mostra o papel do shopping center, edifício símbolo do século $\mathrm{XX}$, na sua atual configuração urbana e arquitetônica.

\section{A Atividade Comercial, o Homem e a Cidade}

Desde os primeiros tempos da história da humanidade, a atividade comercial é condição essencial para o surgimento e crescimento das cidades, ao lado da motivação inicial de defesa e sede de poder. O comércio foi o grande responsável pela distribuição de bens e serviços, e o do tipo espontâneo, foi o pioneiro. No princípio como atividade individual e posteriormente como coletiva, com a consciência desenvolvida de que a concentração de atividades num determinado local ofereceria diversas vantagens, inclusive com maior atração dos consumidores.

Inicialmente, a "troca" de mercadorias, de informações, de pensamentos, ou outra qualquer, acontecia em espaços públicos, tanto internos quanto externos. Possibilitando o encontro, surgiu o "lugar do mercado". O comércio e as outras atividades sociais, estão portanto, intimamente ligados, desde o princípio. Os locais de troca de mercadorias se constituíram em espaços econômicos, mas também de divertimento, distração, de vida social e política (VARGAS, 2000). O ágora grego, o fórum romano, o bazaar árabe, os mercados medievais, as galerias do século XIX, são alguns exemplos ao longo da história. Com a revolução industrial, pode-se dizer que também ocorreu uma revolução comercial. A tendência do agrupamento, foi se incorporando na atividade comercial, que sendo cada vez mais planejada, foi se estruturando e evoluindo em termos organizacionais e administrativos. Espacialmente, foi abandonando o mercado e áreas públicas, para se estabelecer em espaços individuais, próprios e privados (MASANO, 1993). E assim, em um mundo cada vez mais urbano e capitalista, os pontos externos foram se fechando, até o surgimento do shopping center, edifício decorrente portanto, de inúmeras alterações ocorridas nos últimos 50 anos em diversos aspectos: 
nas formas de comercialização varejista; na intensificação da concorrência; na difusão do transporte individual; na modificação da estrutura urbana; na emergência do consumo de massa; no aumento gradativo do nível de renda da população em geral; no incremento do tempo livre devido às constantes diminuições da jornada de trabalho do cidadão comum; e vários outros (GRASSIOTTO, 2000, p. 4).

Muita coisa mudou no shopping center, desde seu aparecimento, em termos funcionais e espaciais. As necessidades do usuário consumidor, seus hábitos, usos e costumes, assim como a apropriação do espaço. O espaço puramente comercial batizado por (HIRSCHFELDT, 1986), como templo do consumo (galeria de lojas de ambos os lados), hoje representa um espaço cultural, que absorveu as antigas funções do espaço público, que passaram a acontecer em um espaço fechado, e privado. As coisas agora ocorrem num recinto privado, com regras e normas que controlam o acesso a seu interior. O controle de acesso é realizado pelo mix escolhido. Ambiente com aparência de público, presença de bancos, espaços abertos, equipamentos urbanos, paisagismo diferenciado, onde acontecem as atividades culturais, de lazer, entretenimento e o encontro social.

Os shoppings são meios de comunicação sofisticados destinados a reproduzir partes da cultura em formas comerciais simuladas. Eles contam com todas as tecnologias eletrônicas mais avançadas para criar um meio cultural artificial. Motivos arquitetônicos cuidadosamente coreografados, ambientes climatizados automaticamente, esquemas de iluminação sofisticados e sistemas de vigilância computadorizados funcionam conjuntamente para "comunicar" um lugar cultural especial, diferente dos lugares culturais partilhados que existem do lado de fora dos portões do shopping (RIFKIN, 2001, p. 125).

O ambiente é uma mini-cidade artificial.

\section{O Shopping Center no Contexto Urbano}

Segundo Castells (apud VILLAÇA, 1998), o espaço urbano é estruturado, e essa estrutura compõe-se de quatro elementos principais: o centro (com concentração de comércio, serviços e emprego); os subcentros (réplicas do centro agrupando comércio e serviço diversificado); os bairros residenciais (diferenciados por classes sociais); e as áreas industriais. Na economia capitalista, as leis de mercado é que regem toda a organização do espaço. É mais forte que a interferência do estado, comandando a distribuição de bens e serviços originados do trabalho. Segundo Gunn (1985b), desde os dias iniciais da colonização do Brasil, tivemos a ação estatal sobre o território (na forma de leis, projetos, planos diretores, incentivos financeiros, intervenções com obras, e outros), como influência inquestionável no desenvolvimento das várias regiões, cidades e bairros.

Para Masano (1993, p.36), “o entendimento da formação da cidade, das suas condições morfológicas e climáticas, da distribuição do uso do solo, da legislação sobre o zoneamento, são elementos que permitem subsidiar a decisão sobre a localização do comércio". Segundo Lima Filho (1971), o crescimento das cidades tende a separar seus setores de atividades gerando aumento de tráfego de bens e pessoas. Nesse sentido, ocorrem três tipos e momentos de ajustamentos do sistema varejista na malha urbana: o primeiro nas áreas do centro comercial principal da cidade; o segundo, quando ocorre a descentralização ao longo de vias radiais principais e a tendência locacional não planejada para o centro de vários núcleos da área urbana; o terceiro implica a mudança para localizações planejadas não centrais e com extensas facilidades, que permitem compras em única parada e estacionamento próprio. É desse último segmento que fazem parte os shopping centers tradicionais ${ }^{3}$, enquanto que aqueles que tem

\footnotetext{
3 Os shopping centers surgiram primeiramente na periferia e o processo de seu desenvolvimento resultou na definição de vários "tipos". São três os básicos e tradicionais: o de vizinhança, o de comunidade e o regional, classificação dada pelo tipo de loja âncora (estabelecimento que atrai um maior número de consumidores para o shopping - lojas de departamentos, de variedades, de departamento júnior, supermercado), área total construída e raio de abrangência (HIRSCHFELDT, 1986). O mais difundido no Brasil é o regional, que tendo entre 30.000 e $100.000 \mathrm{~m}^{2}$, oferece uma linha completa de mercadorias, ancorando-se com uma ou duas lojas de departamento, além de supermercado. Sua área de influência abrange um raio entre 15 e 20 km, dependendo dos
} 
como intenção a revitalização de áreas deterioradas, se instalam em áreas centrais.

Para Sudjic (1999), o shopping center, ao lado dos modernos aeroportos e museus, é um dos edifícios mais importantes e estruturadores da nova paisagem urbana, espaço "público simulado", definidor da cidade contemporânea. O estudo de suas particularidades é fundamental para a compreensão do direcionamento futuro do setor terciário, principalmente por que existe a possibilidade de implantação de novos centros comerciais mais sustentáveis em si e sua conseqüente participação na sustentabilidade das cidades de um modo geral.

\section{O Exemplo de Londrina}

- Origens e Vocação Comercial da Cidade

Londrina, cidade do norte do Paraná, faz parte do terceiro planalto, uma das cinco regiões naturais do estado, uma região extremamente fértil, de terra roxa propícia à agricultura. O povoamento começou fora dessa área, as primeiras penetrações cruzaram o médio e o alto Itararé em 1860. Em 1862, os primeiros povos vieram procedentes da colônia mineira de Siqueira Campos. O povoamento progrediu de leste para oeste atingindo o terceiro planalto com os primeiros habitantes se instalando em Jacarezinho (1900) e Cambará (1904). Nesse período começou a invasão do café, com o surgimento de fazendas nos moldes paulistas (BERNARDES, 1953).

Ourinhos, situada na fronteira dos estados de $\mathrm{S}$. Paulo e Paraná, tornou-se a porta de entrada do norte do Paraná com a estrada de ferro Sorocabana em 1908. O desenvolvimento da iniciativa privada aí iniciou-se com os trabalhos de colonização da CTNP (Cia. de
Terras Norte do Paraná), que adquiriu os interesses do ramal ferroviário e começou o prolongamento da estrada de ferro, que atingiria Londrina em 1935 (FRANÇA, 1960). Na sua passagem encontrou a colônia militar de Jataí, de 1855, de cujo desmembramento surgiria Londrina (Figura 1).

Lord Lovat (Simon Joseph Frazer), assessorado pelo escocês Arthur Thomas, com uma visão extraordinária da vasta expansão agrícola e industrial que estava reservada para a região, juntamente com empresários ingleses, comprou 515.000 alqueires paulistas, parte em 1925 e parte em 1927, com o objetivo de obter terras para o algodão. Resolveram lotear a área em pequenas propriedades. Fundaram a "Paraná Plantations Company" que, percebendo a importância de boas vias de comunicação desdobrouse em duas subsidiárias: a CTNP, que passou a tratar da colonização, e a Cia. Ferroviária S. Paulo Paraná, que com a compra do ramal ferroviário, estendeu os trilhos até as zonas de loteamento (GRASSIOTTO, 1975). Londrina, acabou se beneficiando de um processo migratório de paulistas em busca da expansão de áreas cafeeiras, proporcionado por ações governamentais (1906) em prol da construção e ampliação da malha ferroviária do território paulista. "Neste período quando a Araraquarense e a Sorocabana atingem o oeste do território paulista, a expansão do café alterou seu sentido direcional, também cruzando o Rio Paranapanema e seguindo uma direção sudoeste ao norte do território paranaense" (GUNN, 1985a, p. 23). O espigão divisor de águas Ivaí / Paranapanema, foi o eixo de colonização (rodoviário e ferroviário) e a distância estipulada entre os núcleos urbanos foi de $15 \mathrm{~km}$. O loteamento iniciou-se em 1933, e seguindo planos pré-determinados, os lotes foram

fatores de acessibilidade e mix de lojas, podendo atender até 300.000 habitantes, em função do seu padrão, tamanho e características sócio-econômicas locais. Se ultrapassar $75.000 \mathrm{~m}^{2}$, e possuir mais lojas de departamento, pode ser considerado super-regional. Variações tipológicas foram ocorrendo ao redor desses três tipos, como reflexo das alterações de valores da sociedade de consumo, a cada diferente momento histórico. Hoje existem shoppings temáticos, os sem âncora, os outlets (diretos da fábrica), lojas destino, os especializados, etc.. A mais interessante variação é o shopping vertical, surgido a partir da década de 70, com incorporação de conceitos europeus do grande magazine do séc. XIX. É geralmente implantado em terrenos menores, mais valorizados, em regiões centrais, muitas vezes com o objetivo de revitalização de áreas em processo de decadência. Possui geralmente vários pisos, com circulações verticais e arquitetura característica, em oposição aos clássicos horizontais, que geralmente são implantados na periferia. 
implantados dos espigões para os vales, com frente para a aguada e estradas, tendo área média de 16 alqueires paulistas (FRANÇA, 1960). Em 1939, a Paraná Plantations Company perdeu a estrada de ferro encampada pelo governo federal e a CTNP foi vendida a um grupo paulista, a Cia Melhoramentos Norte do Paraná, que, mesmo sob nova administração, não mudou a orientação de colonização.

Londrina, hoje com quase $70 \mathrm{anos}^{4}$, desenvolveuse com a cultura do café, e por meio dela mostrou sua vocação comercial. Surgiu em localização estratégica, funcionando como centro de ligação entre as cidades do norte do Paraná (Maringá, Apucarana, Paranavaí e outras) e as grandes capitais (São Paulo e Curitiba) (Figura 2). A ligação com Santos e as cidades do eixo de comunicação, permitiu que se tornasse um centro exportador da produção agrícola, principalmente do café, e importante distribuidor atacadista de produtos diversos, provenientes tanto de regiões brasileiras, como de capitais internacionais. Daí, o seu desenvolvimento como entreposto comercial, e ao invés de se industrializar, cresceu como prestadora de serviços, centro regional de compras, cultura e lazer. Hoje sua área de influência representa cerca de 4,5 milhões de habitantes sendo a área metropolitana composta por 662.789 habitantes (LONDRINA, 2001).

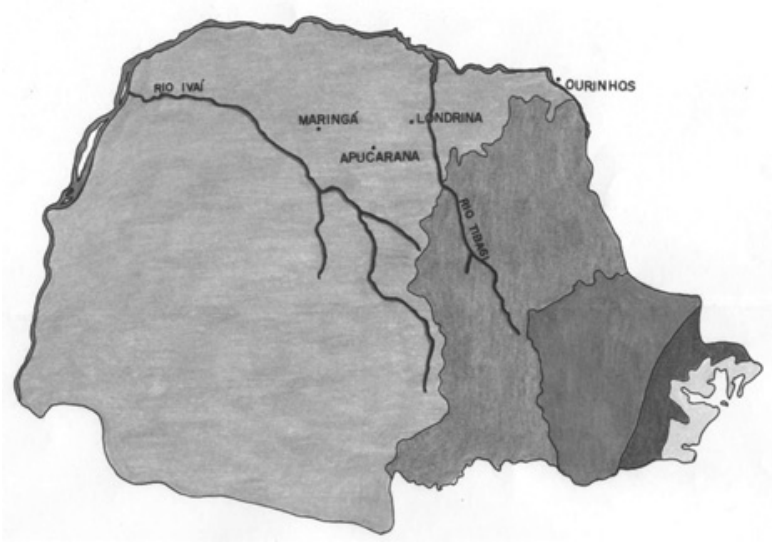

Fonte: Valverde, Orlando, 1957.

Figura 1: As cinco regiões naturais do Paraná.
Portanto, são vários os fatores que explicam o progresso da cidade: os aspectos físicos e localização privilegiada; parcelamento em pequenas propriedades rurais de aproximadamente 16 alqueires; fundação de núcleos urbanos com distância média de $15 \mathrm{~km}$ entre eles, visando a integração pelo eixo de circulação; planejamento de uma espinha dorsal de penetração leste - oeste, para escoamento da produção para Santos, com a criação de uma ferrovia aliada à rodovia (BR 369); a presença do paulista, elemento humano desbravador; e principalmente a visão de futuro e capacidade empreendedora do inglês colonizador, que promoveu a arrancada para o desenvolvimento da região, que acabou por se constituir num dos mais promissores pólos econômicos do país.

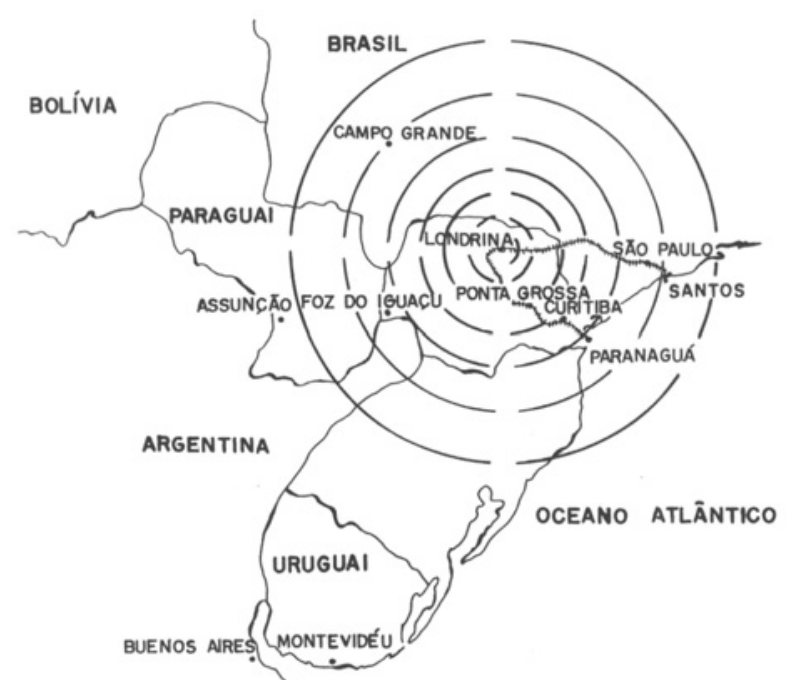

Fonte: Londrina: Diagnóstico e Caminhos, 1993, p. 44.

Figura 2 - Localização estratégica de Londrina.

Em 1999, a cidade contava com 13.512 estabelecimentos comerciais e 12.553 estabelecimentos de serviços, abrigando ainda 43 hotéis e 255 restaurantes (LONDRINA, 2001). Ultimamente, a cidade vem se tornando um pólo educacional, principalmente com relação ao ensino do terceiro grau. Cinco instituições de ensino superior estão instaladas em Londrina, e as maiores são a UEL (Universidade de Londrina) a UNOPAR (Universidade Norte do Paraná) e a UNIFIL (Centro Universitário Filadélfia, antigo Centro de Estudos Superiores de Londrina).

\footnotetext{
${ }^{4}$ Surgiu em 1929 e foi oficializada como sede em 10 de dezembro de 1934.
} 
A área médica também sempre representou um ponto de atração forte para a cidade, com projeção nacional e inclusive internacional, tendo como base a escola de medicina da Universidade Estadual de Londrina, possuidora de um corpo docente do mais alto nível técnico. Esses vários fatores favorecem a existência de um grande contingente de estudantes universitários, que para aqui trazem riqueza constituindo-se em potenciais consumidores de alta renda. Londrina, desta maneira, cada vez mais vem se transformando em uma referência de turismo científico, artístico e cultural, além de comercial, sendo sede de eventos e congressos nos mais variados segmentos.

Dada a sua formação, a cidade vem sendo ativa participante dos movimentos de vanguarda, inclusive na arquitetura. No auge da economia cafeeira, surgiu a Av. Higienópolis, um mostruário em miniatura da Av. Paulista de S. Paulo, cenário das residências dos barões do café, dignas representantes do ecletismo arquitetônico em vigor naquela época. Logo a seguir, ao instalar-se o movimento moderno, vários arquitetos de renome aqui deixaram sua contribuição, como Vila Nova Artigas e Carlos Cascaldi, em obras como o aeroporto, o cine-teatro Ouro Verde e a antiga rodoviária, hoje Museu de Arte Moderna, tombada pelo seu grande valor histórico e arquitetônico. Contando sempre com empresários empreendedores, já possui obras com alta tecnologia em aço, uma delas projeto do renomado arquiteto Siegbert Zanettini, especializado nesse tipo de estrutura. Os shopping centers aqui implantados, são um outro exemplo da ativa participação de Londrina no cenário arquitetônico nacional e internacional. Todas as obras com utilização de tecnologia de ponta, servem de inspiração e referência para os arquitetos locais, que a cada momento histórico, têm colaborado com a elaboração de uma nova imagem da cidade. Uma cidade que além do seu já consolidado sucesso econômico como "capital mundial do café", possa ser lembrada, como progressista e participante das mais diversas correntes da arquitetura contemporânea.

\section{O Crescimento e a Evolução Urbana da Cidade, até o Aparecimento dos Shopping Centers}

O desenvolvimento arquitetônico de Londrina, não pode ser estudado fora de seu tecido urbano, parte integrante de uma estrutura maior, a da dimensão histórica. Dimensão essa, de sonhos, criações, realizações, crescimentos e transformações efetuadas pelo habitante local, "um cenário dinâmico, reflexo de uma população cosmopolita e multifacetada ainda construindo suas próprias tradições e que apresentam permanentemente desejo de realizar um lugar para se viver sempre melhor" (MARAGNO apud. SHIMBA; UREN, 1999, p. 5).

Desde os primeiros tempos, a arquitetura de Londrina reflete o desejo de realizações. "Seus marcos são arquiteturas na mais completa autorepresentação de sua historicidade"(SHIMBA; UREN, 1999, p.12). Suas obras se apresentam de forma variada, refletindo valores, acontecimentos diversos, fatos novos e antigos. Mostram contraposições ou mimetismos, influências, impactos ou intercâmbios. Essa característica da arquitetura da cidade é revelada também em seus espaços comerciais, que podem ser classificados em quatro fases evolutivas: a fase pioneira, com a maioria das construções em madeira e soluções construtivas vernaculares; a fase art déco, com edificações em alvenaria, apresentando detalhes característicos deste estilo $^{5}$; a fase moderna, onde se nota claramente a utilização dos princípios de Le Corbusier ${ }^{6}$, e a última fase, o novo ecletismo, da atualidade, onde estão presentes as várias tendências da arquitetura contemporânea, inclusive em um mesmo edifício.

\footnotetext{
5 Arte de estilo decorativo internacional, o art déco se utiliza dos motivos recorrentes do mesmo, e na arquitetura aparecem em altos e baixos relevos na composição de planos horizontais ou verticais. Em Londrina, as construções dessa fase, apresentam efeitos ornamentais em forma de elementos geométricos escalonados ou em ziguezague, com detalhes sinuosos e aerodinâmicos.

6 Seus preceitos são: os pilotis; a ossatura independente; a planta livre; a fachada livre; o telhado jardim; e ainda os brise-soleil.
} 
A planta da cidade de Londrina com o formato atual sudeste-noroeste, teve seu arruamento inicial, elaborado pelo engenheiro Alexandre Rasgulaeff (SCHWARTZ, 1997), em forma de tabuleiro de xadrez, o que explica a existência de inúmeras ladeiras (Figura 3). O assentamento se deu no espigão, onde o nascimento de vários córregos, propiciaram um sítio urbano adequado em termos de topografia, favorecendo o problema da água e drenagem local. No primeiro momento a cidade cresceu acompanhando as vias de comunicação em sentido leste-oeste, primeiramente eixo ferroviário e logo a seguir, também rodoviário. Com o tempo, o homem em suas adaptações do espaço, promoveu a alteração da direção de crescimento e desenvolvimento da cidade para a norte-sul, com a criação de seu mundo edificado.

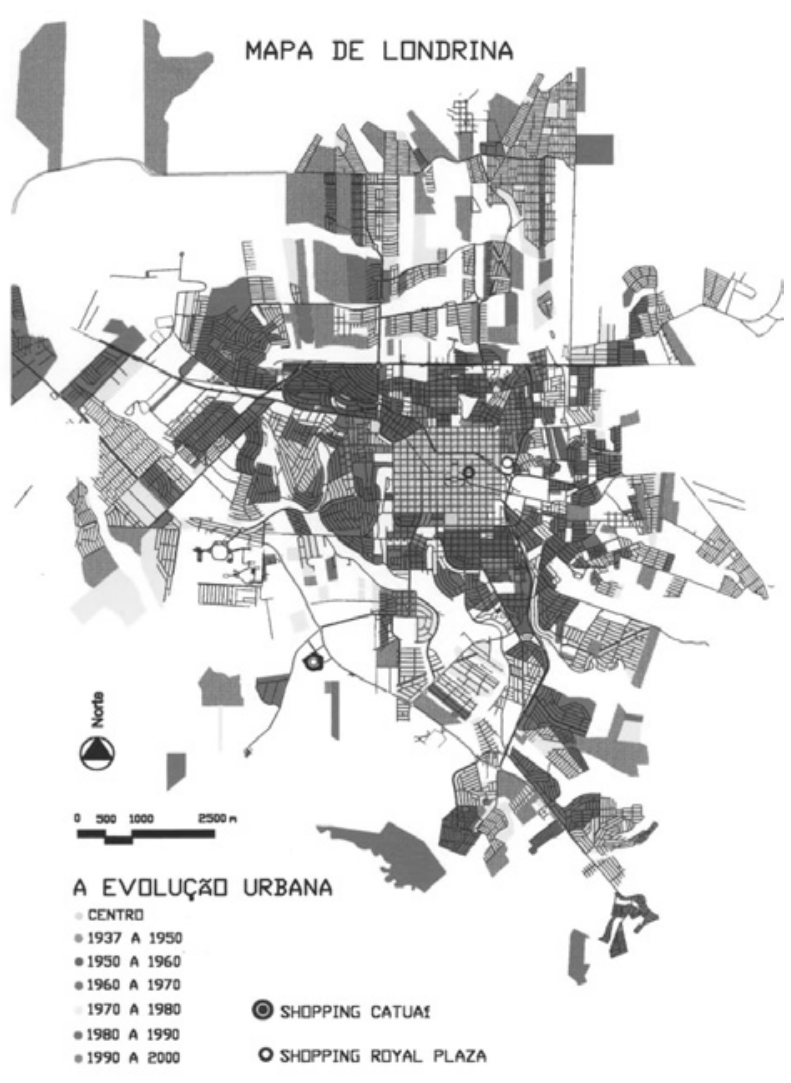

Fonte: Grassiotto (1980); (Dados cadastrais, PML), 1980, 2000.

Figura 3 - A evolução urbana de Londrina
A Av. Paraná foi a primeira rua, continuação da rodovia que vinha de Ibiporã e ia em direção a Cambé (Figura 4). As primeiras construções se instalaram no cruzamento dela com a Marechal Deodoro, por esta ser via de acesso ao Heimtal, hoje área do município. A expansão partiu da Av. Paraná em direção à praça Willie Davis e daí para oeste em direção a Cambé. A região entre a Av. Paraná e a linha férrea foi a que mais se desenvolveu.

As primeiras vilas apareceram dentro do tabuleiro de xadrez, ao norte e a leste da cidade, num traçado desordenado, em áreas economicamente mais pobres. A estrada de ferro foi desde os primeiros tempos uma barreira, favorecendo o desenvolvimento de uma região de classes populares ao norte e outra de classes mais abastadas ao sul, área mais propícia à expansão devido à suavidade topográfica e à

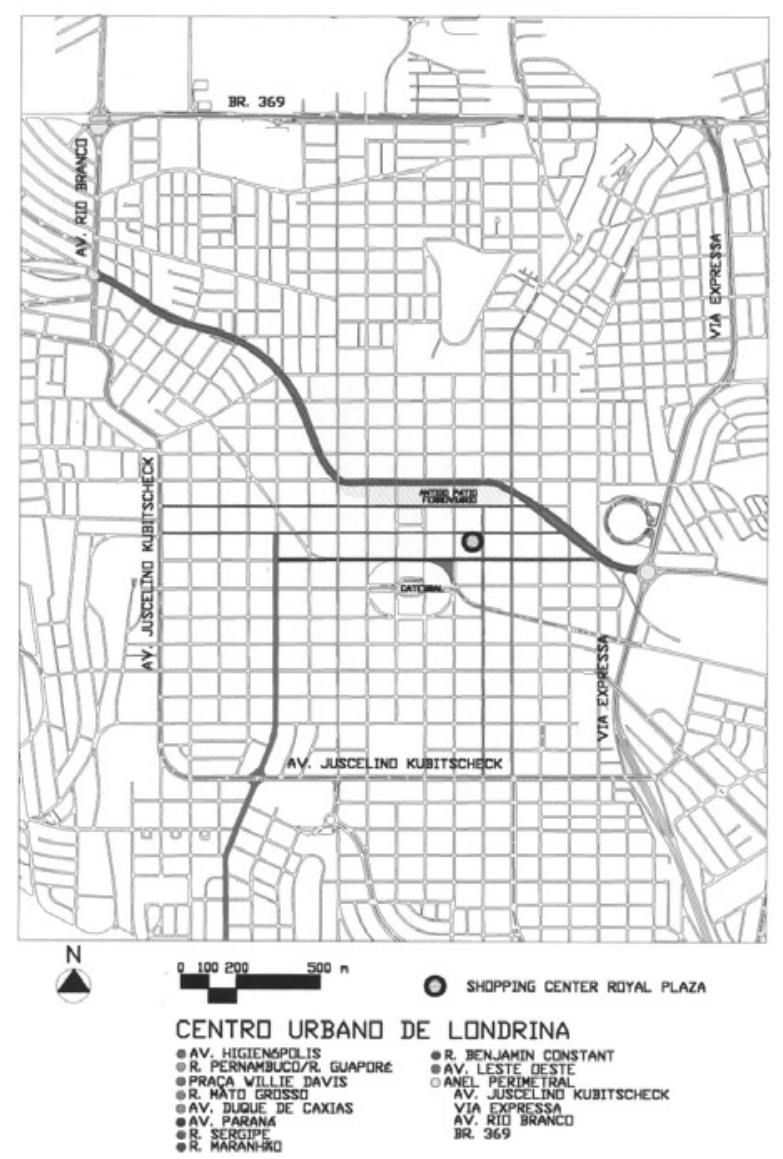

Fonte: do autor, 2000.

Figura 4 - Centro Urbano de Londrina. 
proximidade do centro (Figura 5, 6). A $300 \mathrm{~m}$ da catedral, o pátio ferroviário localizava-se no "centro principal" da cidade, situado entre as ruas Benjamin Constant, Leste-Oeste, Duque de Caxias e Pernambuco (Figura 7, 8). Com a retirada do antigo leito da via férrea desse local (Leste-Oeste), o pátio foi transferido para o distrito industrial (CILO II centro industrial de Londrina II), e foi desativado em 1982 (GRASSIOTTO, 2000).

$\mathrm{O}$ advento da segunda guerra mundial refreou o crescimento de Londrina, que sofreu também a primeira grande geada nos cafezais em 1942. Somente em 1944, é que o desenvolvimento urbano tomou novo impulso, com a valorização do café, e em 1946 começaram a surgir novas vilas, desenvolvidas fora do tabuleiro de xadrez. Um plano urbanístico foi elaborado pela Prefeitura em 1948, e tinha por objetivo o adensamento e a colocação de um freio no crescimento desordenado da mesma. Essas medidas provocaram a valorização de terrenos

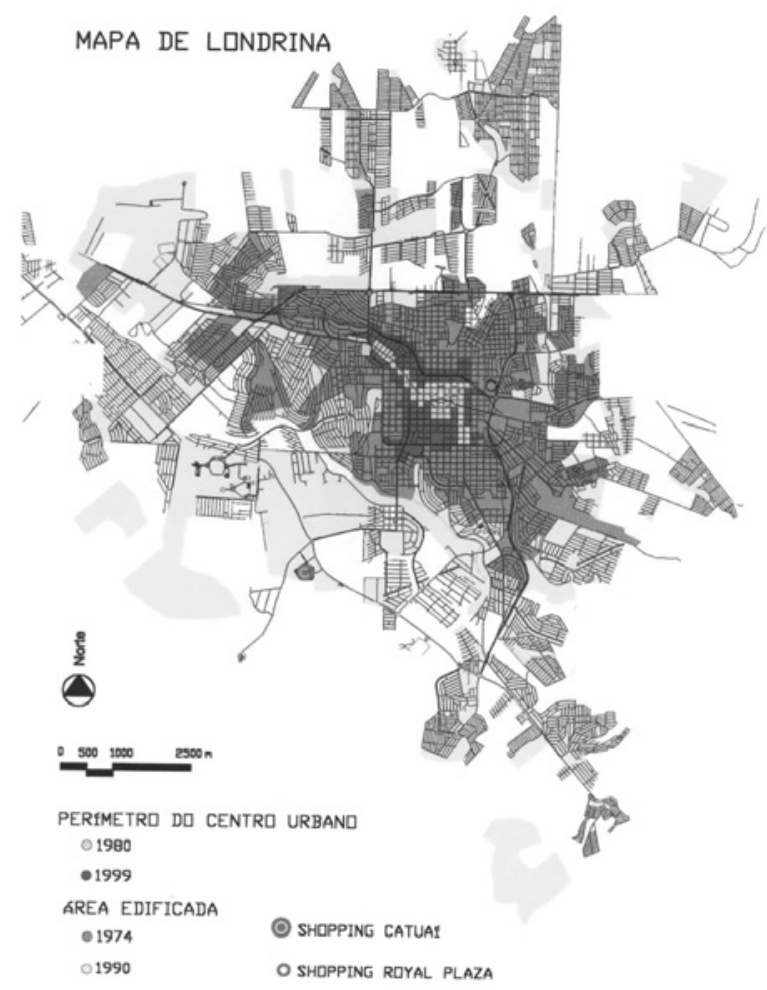

Fonte: Pesquisa AUP 838, MINTER FAU/USP - DAU/UEL, 1999.

Figura 5 - Perímetro do centro urbano.

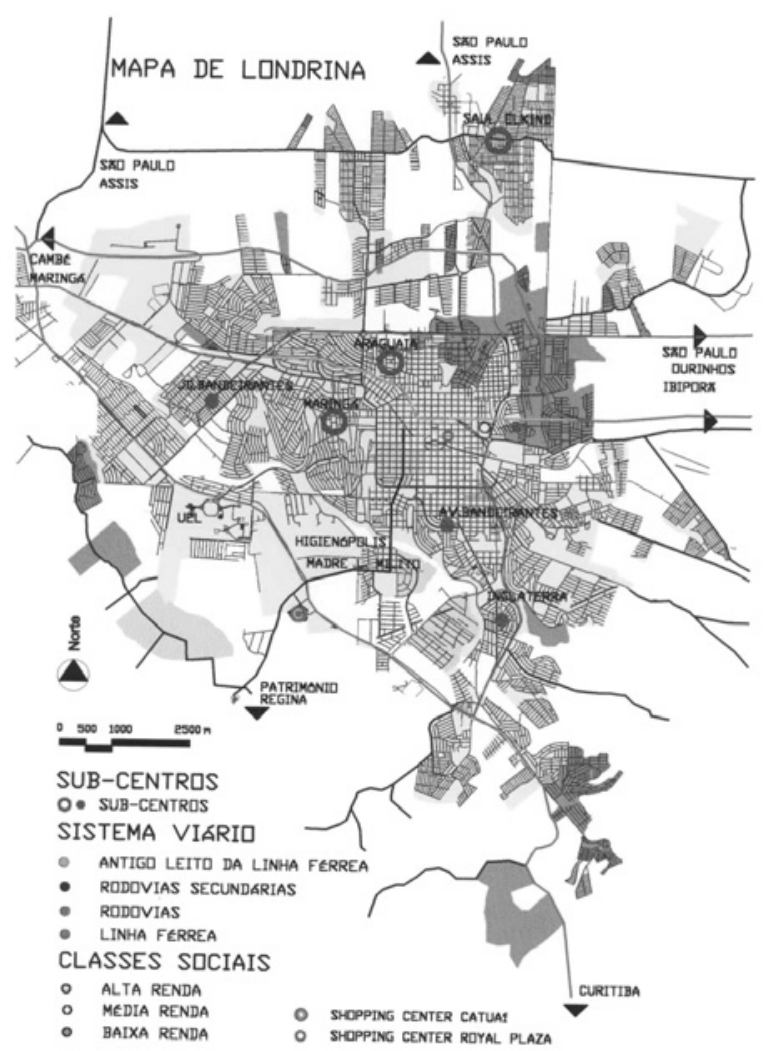

Fonte: Pesquisa AUP 838, MINTER FAU/USP - DAU/UEL, 1999.

Figura 6 - Subcentros, classes sociais, sistema viário.

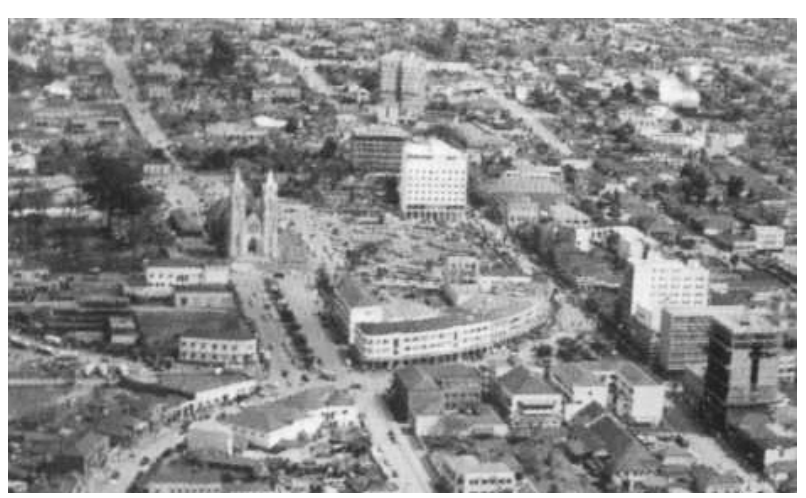

Fonte: Londrina, uma grande cidade no coração do Mercosul, 1997 , p. 3.

Figura 7 - O centro antigo com a catedral. 


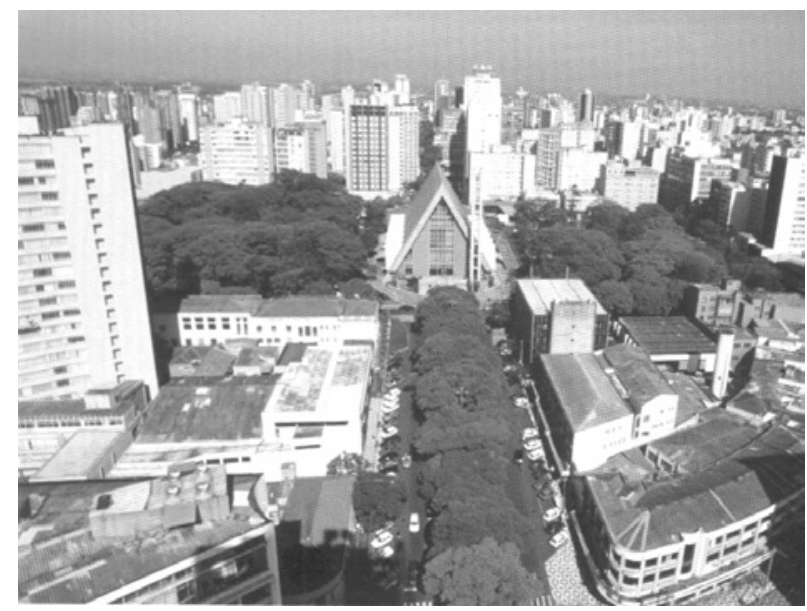

Fonte: Londrina, uma grande cidade no coração do Mercosul, 1997, p. 4.

Figura 8 - O centro novo com a catedral.

urbanos e um desenvolvimento mais marcante a partir de 1952-1953, com o auge da economia cafeeira (GRASSIOTTO, 1980).

As áreas funcionais de Londrina, mesmo sem planejamento, foram-se delineando naturalmente. Juntamente com a expansão das áreas residenciais, acontecia também a expansão dos outros setores, comercial, de serviços e industrial.

A primeira zona comercial de Londrina, a partir de 1935, localizou-se entre a estrada de ferro e a Av. Paraná, mas essa área não foi exclusivamente comercial (Figura 4). Como já foi mencionado, nos arredores da Marechal Deodoro também surgiram as primeiras residências, e isso confirma, que a atividade comercial está sempre acompanhando o mercado consumidor. Em 1935, inauguraram-se as Lojas Pernambucanas, na esquina da avenida Paraná com Av. Rio de Janeiro, local em que elas se encontra até hoje, após uma série de reformulações. Os espaços comerciais dessa época histórica se localizaram nas imediações das ruas Minas Gerais, Maranhão, Mato Grosso, Bahia, Sergipe, Quintino Bocaiúva e das avenidas Rio de Janeiro e Paraná.

A segunda zona comercial de Londrina estabeleceu-se nas imediações da praça Willie Davis, na Av. Paraná, entre as ruas Mato Grosso e
Pernambuco, além da rua Sergipe (Figura 4). Todas elas se situavam nas proximidades da avenida Paraná, região do comércio mais fino, composto de comerciantes dos mais diversos ramos, área que constituia o centro principal da cidade. Na região entre o antigo pátio ferroviário e a avenida Paraná, formou-se uma área de uso misto, residencial, comercial e industrial. Somente em épocas mais recentes, é que as indústrias se mudaram para zonas especiais e mais periféricas. A leste da cidade, instalaram -se depósitos de cereais e café, máquinas, serrarias, fábricas etc..

Convém salientar, neste momento, que a grande prosperidade e enriquecimento trazidos pelo dinheiro advindo do café serviu para nutrir a economia da cidade e a futura consolidação da região Norte do Paraná. O fluxo migratório constante propiciou o desenvolvimento da vocação da cidade como entreposto comercial, e seu acentuado crescimento e expansão extrapolaram a previsão inicial. Com o comércio sempre acompanhando as áreas residenciais, rapidamente Londrina teve seu centro urbano delineado tanto na sua configuração paisagística quanto arquitetônica (SHIMBA; UREN, 1999). O êxito financeiro do café favoreceu uma ocupação seletiva da malha urbana, na qual o Norte da linha férrea foi tomado por camadas populares, e o Sul/Sudoeste se constituiu em região de formação de bairros nobres (Figura 6). Na década de 40, a Av. Higienópolis, cortando a cidade do centro para o Sul, apresentou-se como uma área diferenciada, abrigando as primeiras residências dos homens ilustres, os barões do café, e assim transformou-se na zona residencial mais elegante daquele momento. A avenida foi construída como um retrato das mansões das Avenidas Paulista e Brasil (em São Paulo), reproduzindo a cultura burguesa daquela fase eclética da arquitetura brasileira. Atualmente, a avenida se transformou em área de expansão comercial, devido à instalação do shopping center Catuaí. Por causa da ligação com a rua Madre Leonia Milito ela se constitui na principal via de acesso ao centro comercial (Figura 9). 


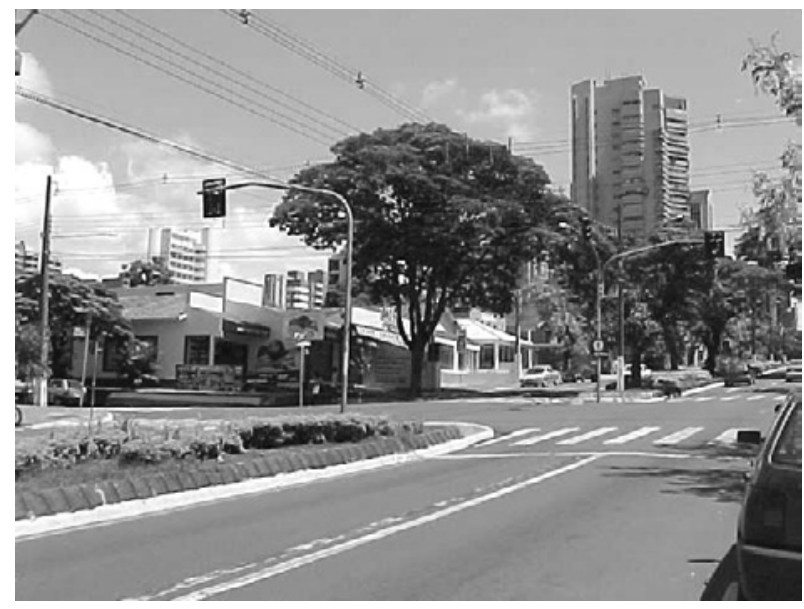

Fonte: foto do autor, nov. 2000.

Figura 9 - A avenida Higienópolis atual.

A instalação de grandes empresas atacadistas em Londrina e nas demais do eixo de comunicação, propiciou a afirmação definitiva da atividade comercial no Município. Em 1950, o número de casas comerciais era maior do que a população de Londrina comportaria. Esse fato pode ser explicado, pelo enorme fluxo diário de pessoas, advindas de cidades vizinhas, e isso sinaliza a função de pólo de uma região maior, com grande contingente populacional.

Até 1945 , as poucas vilas que surgiram situavamse ao redor da avenida Paraná. De 1945 a 1950, a expansão predominante ocorreu para o norte, com crescimento de regiões populares. De 1950 a 1960 , a expansão maior foi para noroeste, acompanhando o espigão, datando desta época o primeiro loteamento ocupado pela classe alta, o Jardim Shangri-lá. Foi nesse bairro, que apareceram as primeiras residências com características modernistas, a corrente arquitetônica em evidência naquele momento. Podese dizer que foi um bairro de difícil desenvolvimento, pois instalou-se a noroeste, e a tendência para sulsudoeste já havia se delineado para a formação de bairros elegantes. De 1965 a 1970, o Campus Universitário se instala no quadrante sudoeste, abrindo caminho para a expansão do centro nesta direção (Figura 3, 5).

A cada melhoramento ou intervenção feita pela prefeitura ao longo dos anos, cristaliza-se a tendência de crescimento e expansão da cidade para sul/ sudoeste, setor das altas camadas sociais e norte, setor das baixas camadas (Figura 6). Entre esses projetos pode-se citar a construção da via expressa ${ }^{7}$, obra de grande importância, tendo completado o anel perimetral da cidade, até então incompleto (1975), constituído pela BR-369, Av. Rio Branco, Av. Juscelino Kubitscheck (J.K., antiga Antonina), rua Jacarezinho, vale do córrego das Pombas e Av. Presidente Wilson (Figura 4). Provocou a integração da malha urbana com muitas obras complementares como viadutos, canalização de córregos, obras diversas de drenagem, urbanização e saneamento. Sua construção, que não aconteceu por acaso, resolveu vários problemas viários e de integração urbanística, e a partir dela abriu-se espaço para a expansão sul, sudoeste, ou mesmo norte, desencadeando novos negócios imobiliários.

O projeto CURA ${ }^{8}$, iniciado em 1973, promoveu a integração à malha urbana de áreas saneadas com erradicação de esquistossomose, canalização de córregos, revestimentos de taludes, obras de proteção e transposição de bueiros, barragens e galerias pluviais, e pavimentação das ruas de abrangência. Foi a partir desse projeto, que o lago Igapó, passou a ser o cartão postal da cidade. A construção da barragem e urbanização (com projeto de Burle Marx), transformou o local numa zona especial de chácaras e casas de fins de semana da alta burguesia, instalada no final da Av. Higienópolis.

\footnotetext{
7 Avenida de 8,5 km que cortou a cidade de norte a sul, ligando a BR 369 à PR 445, ao longo do ribeirão Cambezinho. Hoje chamase Avenida 10 de Dezembro.

8 CURA - Comunidade Urbana para Recuperação Acelerada. Seu objetivo previsto no plano diretor de Londrina de 1968, era a realização de obras de saneamento e proteção das bacias, assim como a criação de zonas de recreação e desenvolvimento de áreas urbanas estagnadas em regiões de localização estratégica.
} 
Fortalecendo ainda mais a tendência de expansão da cidade para sul-sudoeste, em 1982, a Prefeitura Municipal mudou-se para essa região.

Nas décadas de 50, 60 e até 70, a cidade passou por um intenso processo de verticalização, e foi neste momento que surgiram em profusão os edifícios modernistas, com utilização de muito concreto, vidro e pastilhas, baseados nos preceitos de Le Corbusier. A partir daí, a cidade passou a contar com exemplares construídos dentro dessa tendência arquitetônica, e a liberação do espaço térreo pelos pilotis, propiciaram o aparecimento das galerias comerciais, tão características, abrigando as novas lojas e boutiques. Era o início do comércio em "mall" coberto, acontecendo também em Londrina, da mesma forma que no mundo e outras cidades brasileiras, um momento de transição para a chegada do shopping center.

Fazendo parte deste momento moderno da arquitetura londrinense, foi inaugurado em 23 de outubro de 1973, o shopping center Com-Tour, o primeiro da região sul e o segundo brasileiro, antecedido apenas pelo Iguatemi de S. Paulo. Foi ainda o primeiro shopping da América Latina a se associar ao Conselho Internacional de Shopping Centers, sediado em N. York. Com 13.289,12 $\mathrm{m}^{2} \mathrm{de}$ área construída, num terreno de $20.734,00 \mathrm{~m}^{2}$ na Avenida Tiradentes (eixo leste-oeste) foi um importante marco para Londrina, sendo motivo de visitas de estrangeiros, que queriam conhecer a nova modalidade de edifício comercial, "e também um expressivo símbolo da pujança econômica de nossa cidade" (O COM-TOUR..., 2000), que continuava a se manifestar. O projeto arquitetônico foi inspirado no Dadeland de Miami, no qual as circulações ortogonais eram descobertas, permitindo a ventilação natural (Figura 10,11). Foi concebido como shopping regional, pelo arquiteto Luiz César da Silva de Londrina e está previsto que ele teria uma grande área de abrangência( Norte e Sudoeste do Paraná, até Cascavel e Foz do Iguaçu). De fato, nos primeiros momentos, ele foi um sucesso, mas ao longo dos anos, (contrariamente à atitude do Shopping Iguatemi de S. Paulo),não fez as reformulações necessárias para acompanhar as transformações dos novos anseios da sociedade e incorporá-las em seu espaço comercial. O Shopping Com-Tour nada fez para se atualizar e, por isso, acabou perdendo seu caráter regional, e hoje se apresenta como um shopping de

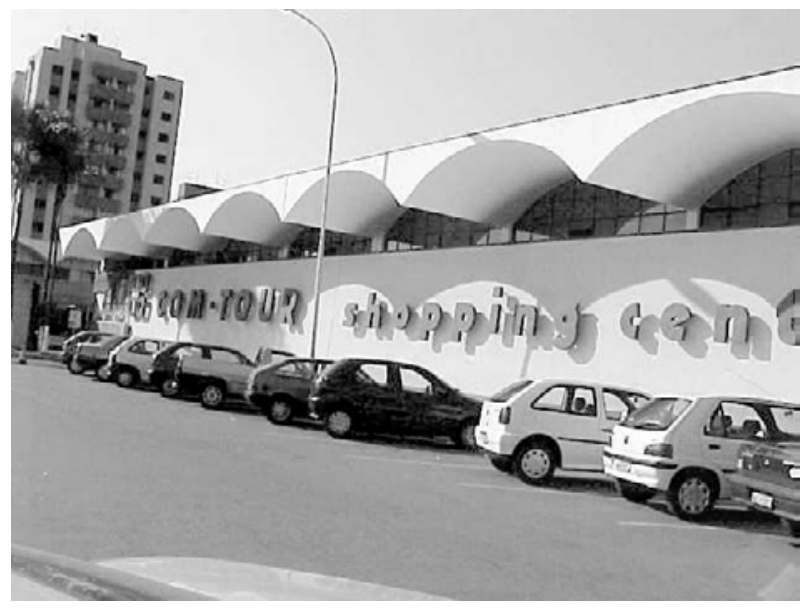

Fonte: foto do autor, set. 2000.

Figura 10 - Com Tour Shopping Center - fachada.

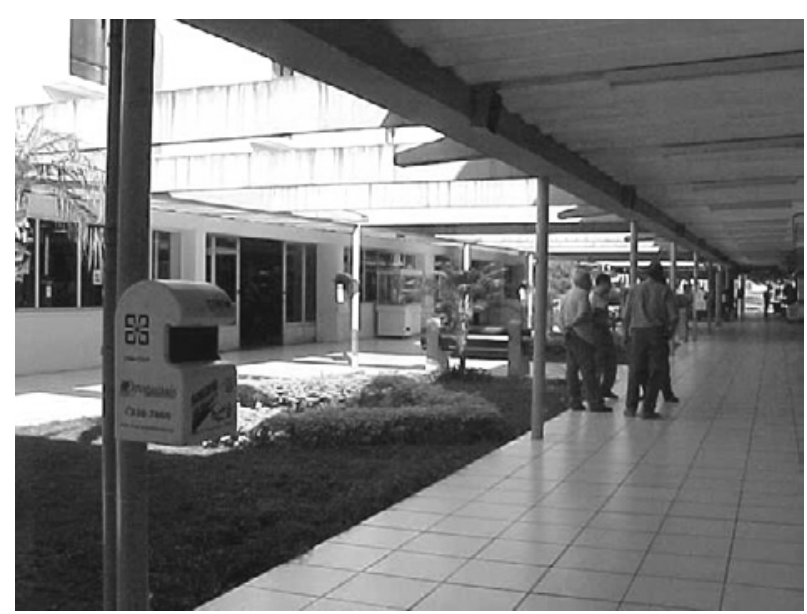

Fonte: foto do autor, set. 2000.

Figura 11 - Com Tour Shopping Center, circulações internas.

9 mall $=$ rua. 
vizinhança. Em parte, sua decadência pode também ser explicada, por ter sido implantado no eixo lesteoeste, em direção não condizente com a expansão das classes abastadas, que era o sul/sudoeste.

É de 1983 o primeiro projeto de zoneamento completo colocado em prática pela Prefeitura Municipal. Até então, as iniciativas de ordenamento do espaço urbano foram pontuais, principalmente tendo em vista a regulamentação das áreas industriais.

Deve-se colocar neste momento que, em Londrina, o processo de evolução e desenvolvimento de sua atividade comercial aconteceu de conformidade com os ajustamentos definidos por Masano (1993), anteriormente mencionados. As atividades comerciais se instalaram primeiramente no centro ${ }^{10} \mathrm{da}$ cidade e aos poucos foram se expandindo pelas radiais principais a partir do centro, fazendo surgir subcentros ${ }^{11}$ espontâneos, como podemos citar: os das ruas Araguaia, Maringá e Saul Elkind, os maiores; e os da Av. Bandeirantes, da Av. Inglaterra e Jardim Bandeirantes, menores. Depois disso, surgiu o shopping Com-Tour, planejado, na Av. Tiradentes naquela época, periférica, e somente nos anos 90 é que apareceram os grandes shoppings, empreendimentos imobiliários (Figura 5, 6).

Em novembro de 1990, foi inaugurado o Catuaí Shopping Center, super-regional, tradicional, horizontal, projeto imobiliário rigorosamente planejado, com base em pesquisa de viabilidade, instalado na periferia da cidade, na área de expansão das classes abastadas no quadrante sudoeste. Suas condições de implantação favoreceram a descentralização urbana. Em novembro de 1999, foi inaugurado o segundo shopping de grande porte da cidade, o Shopping Royal Plaza, regional, vertical, sem âncora, implantado no coração da cidade, em seu centro tradicional, na esquina das ruas Maranhão e Mato Grosso. Apesar do pouco tempo de funcionamento, já é possível se perceber sua contribuição para a revitalização do centro antigo da cidade.

A partir da instalação do Shopping Catuaí, novos bairros surgiram em direção ao shopping, e com a tendência natural do comércio acompanhar o mercado consumidor, a zona comercial iniciou sua expansão em direção a ele, provocando inclusive alteração no zoneamento da cidade. O centro principal expandiu-se para a Higienópolis, reduto comercial das elites, ultrapassando o Lago Igapó, seguindo pela rua Madre Leonia Milito em direção ao Catuaí.

A consolidação desse sentido de crescimento e desenvolvimento da cidade levou consigo, além do comércio, o sistema viário, a infra-estrutura urbana, o lazer, e outros. Os maiores investimentos, tanto do setor público, quanto do privado, têm acontecido nessa direção: a abertura da rua Madre Leonia Milito; a construção do centro de eventos; a transposição dos córregos pela rua Maringá e paralelas; o aterro de parte do Igapó; e a abertura de inúmeros loteamentos.

\footnotetext{
${ }^{10}$ O perímetro do centro urbano de Londrina foi delimitado conforme Villaça (1998) que considera: centro típico - lojas médias e grandes bancos, serviços (hotéis, atendimento pessoal, escolas não oficiais, etc.); não é típico do centro - lojas pequenas com até cinco metros de frente, postos de gasolina, supermercado; limites - é centro quando mais de $50 \%$ da frente de uma determinada quadra está ocupada por comércio típico de centro.

${ }^{11}$ Os subcentros da cidades são todos diversificados, típicos, antigos, estabelecidos ao longo dos anos. Cada um com sua área de influência, diferindo entre si em função de seus serviços. Quatro deles estão localizados na região das classes de alta renda. A Av. Higienópolis unido à Av. Madre Leonia Milito, caminha para se constituir num subcentro especializado (não diversificado).

${ }^{12} \mathrm{O}$ shopping center segundo a ABRASCE (Associação Brasileira de Shopping Centers), é um centro comercial planejado, sob administração única e centralizada. Oferece um composto de lojas atuando em ramos diversificados, comercial ou de serviços, geralmente objetos de locação, sujeitas a normas contratuais. Estacionamento permanente, tecnicamente correto e suficiente, deve também ser colocado à disposição do consumidor. O composto de lojas, mix ou composto de varejo diz respeito à porcentagem entre: a instalação de grandes lojas de departamentos; lojas de departamentos júnior; lojas de variedades; lojas de móveis; lojas de alimentos; especiarias e serviços de alimentação; e lojas de mercadorias gerais e vestuário.
} 


\section{- O Shopping Center Catuaí e a Descen- tralização Urbana}

O início da história dos shopping centers $^{12}$ ocorreu no Estados Unidos por volta dos anos cinqüenta, quando o governo realizou uma série de incentivos para a ocupação do subúrbio pelos veteranos de guerra (as casas com jardim). A crescente deterioração dos centros, o advento do automóvel, as novas formas de comercialização varejista, a emergência do consumo de massa, o aumento do nível de renda da população, e as novas tecnologias fizeram com que as populações de renda elevada procurassem regiões mais afastadas para morar com tranqüilidade. O comércio seguiu a população consumidora, e o aparecimento dos subcentros aconteceu naturalmente.

Os shopping centers surgiram então, como resultado de alterações na organização de áreas comerciais, que respondessem às diversas transformações da economia e da cidade naquele momento. A Revolução Industrial, a eclosão do comércio internacional, as concentrações populacionais e as conseqüentes transformações na economia e as mudanças tecnológicas foram fatores determinantes na alteração da forma de apropriação do espaço destinado às atividades varejistas (VARGAS, 1993).

Construído como os shopping americanos tradicionais, na periferia, o Catuaí ${ }^{13}$, possui 59.693,77 $\mathrm{m}^{2}$ de shopping, $92.266 \mathrm{~m}^{2}$ de área total e 35. 617,80 $\mathrm{m}^{2}$ de $\mathrm{ABL}^{14}$, ocupa o primeiro lugar no norte do Paraná e o quarto no Brasil (Figura 12, 13). Oferece: ambiente climatizado; 2.300 vagas de estacionamento; 4 âncoras - Supermercado Carrefour, Lojas Americanas, Casas Pernambucanas e Magazine Luiza; 180 lojas; 13 quiosques; 5 salas de cinema multiplex; praça de alimentação; praça

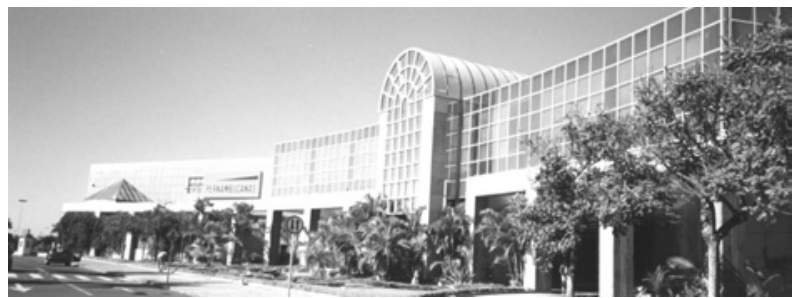

Fonte: foto do autor, set. 2000

Figura 12 - Catuaí Shopping Center - fachada principal

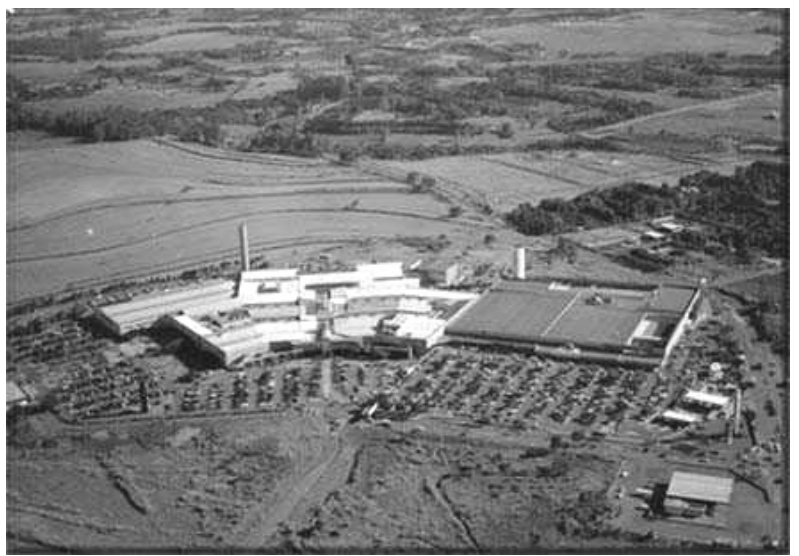

Fonte: Catuaí Shopping Center (2000)

Figura 13 - Catuaí Shopping Center - vista aérea.

de restaurantes; praça de eventos; parque de diversões; boliche; bingo; boate; diversões eletrônicas; 1 cursinho; centro de estética e agora também, um centro de eventos.

A pesquisa realizada pela empresa Bernard Kaplan serviu como parâmetro para o planejamento e viabilidade do empreendimento final. Foram estudadas as regiões primária, a secundária e a terciária; verificadas as necessidades e carências do consumidor envolvido; identificadas as áreas de influência (constatou-se um raio de abrangência de $100 \mathrm{~km}$ ); analisados seu sistema viário, acessibilidade e potencialidades diversas.

\footnotetext{
${ }^{13}$ Catuaí - nome indígena de um tipo de café, muito plantado na região norte do Paraná. Projeto do arquiteto Carlos Alberto Dominguez do escritório Dominguez, Larrea Arquitetura Ltda. de S. Paulo, que possui vasto currículo na área de projeto de shopping centers. Bernard Kaplan realizou o planejamento e estudo de viabilidade.

${ }^{14} \mathrm{ABL}$ - área bruta locável
} 
Profundo conhecedor das origens da cidade, Alfredo Khouri ${ }^{15}$, não teve dúvidas ao escolher a Região Sul, para a implantação de seu shopping center. Mais uma vez, temos aqui, a cristalização da tendência de crescimento da cidade. Segundo seu depoimento, em direção à Curitiba os terrenos são muito acidentados; à leste e ao norte estão concentradas as classes mais populares; em direção à Cambé, existe uma região industrial já consolidada. Sobrou a Região Sul-Sudoeste, mais adequada, localizada em área nobre, com bairros residenciais bem estruturados, região de moradia de uma grande parcela da classe média e alta da cidade (Figura 6). Escolheu, então, para implantação do shopping center, o encontro de duas vias importantes, a PR-445 (rodovia Celso Garcia Cid, estrada para Curitiba), com o prolongamento da Av. Madre Leonia Milito, que se inicia na Higienópolis e ocupa a PR-445, em direção ao patrimônio Regina (Figura 14). Há que se salientar a facilidade de acesso rápido do local às outras cidades da região de influência, ao centro de Londrina, e também saída para Curitiba e São Paulo. Nas proximidades, situa-se o campus da Universidade Estadual de Londrina.

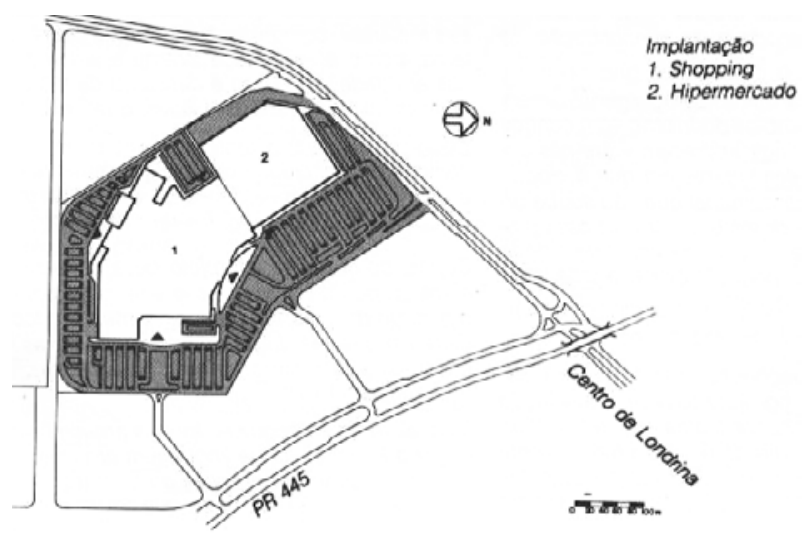

Fonte: PROJETO 137, jan. 1991, p. 58.

Figura 14 - Implantação do Shopping Catuaí
A construção do viaduto de transposição da PR 445, era uma condição necessária para se efetivar a ligação do centro de compras com a cidade. Um ano antes da inauguração, foi feito um acordo entre o município, o governo do estado, e o empreendedor. Este se prontificou a ir fazendo as alças, até que o governo pudesse arcar com a construção do viaduto. A Prefeitura acabou por fornecer as máquinas, o Estado os materiais (pois havia uma pedreira nas imediações), e o empreendedor assumiu as despesas de combustível e mão de obra. Dessa maneira, em pouco tempo as quatro alças estavam concluídas, e não restou alternativa ao governo, senão construir o viaduto, finalizando a obra. A prefeitura, por sua vez, ainda duplicou a Av. Madre Leonia Milito, desencadeando um enorme processo de desenvolvimento naquela região (Figura 15).

Como a transformação da Av. Higienópolis em via comercial já estava em andamento, a duplicação da Madre Leonia Milito acelerou esse processo (Figura 16). Hoje se tem um eixo viário de intenso desenvolvimento, no oferecimento de comércio e serviços especializados, no setor de decoração e materiais de construção.

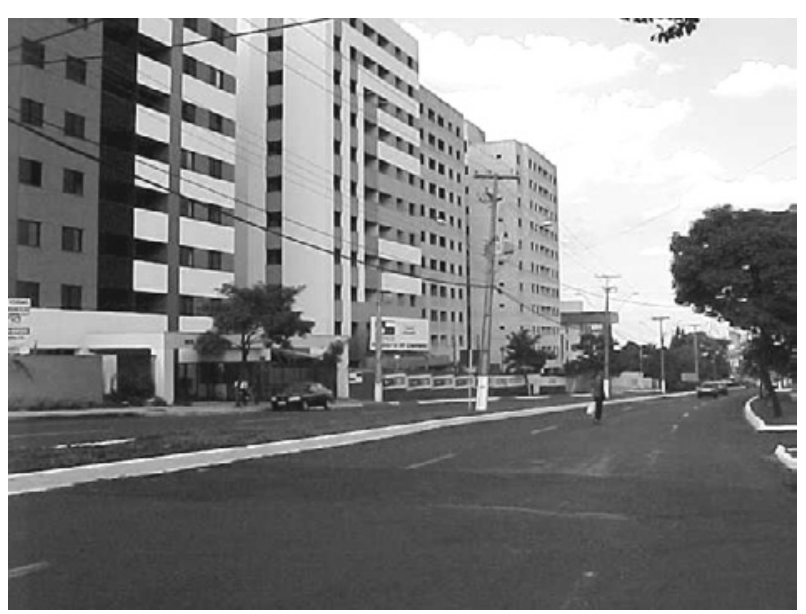

Fonte: foto do autor, set. 2000.

Figura 15 - A Av. Madre Leonia Milito e a verticalização.

${ }^{15}$ Empreendedor do shopping, o engenheiro Alfredo Khouri também dono da Construtora Khouri, responsável pela construção do shopping Catuaí, relatou sua história em entrevista ao autor. 


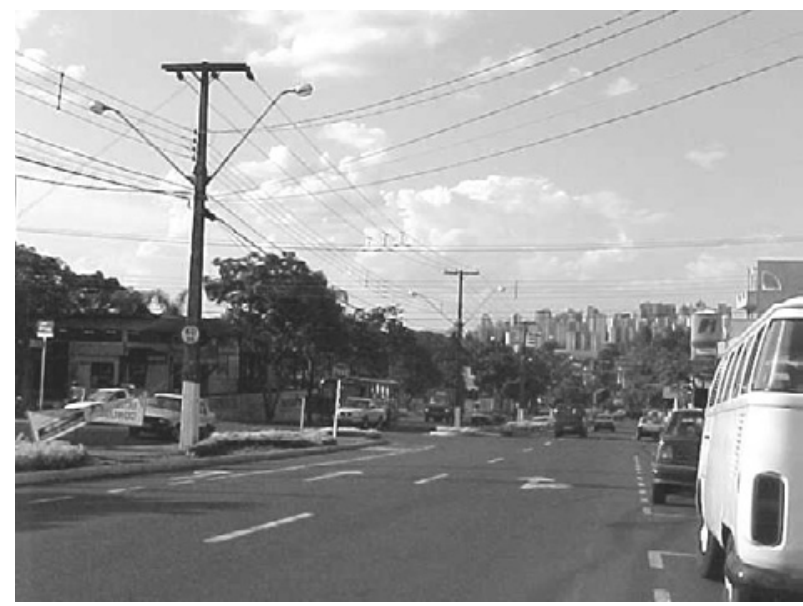

Fonte: foto do autor, set. 2000

Figura 16 - A Av. Higienópolis ligada à Av. Madre Leonia Milito

Como a proximidade entre o local de residência e o local de compras exerce uma forte atração, a instalação do shopping favoreceu o sucesso de vários empreendimentos imobiliários. Conjuntos de edifícios foram construídos, ou se consolidaram, como o Morada do Sol e o Quinta da Boa Vista, na verdade, se constituindo numa pequena cidade com vida própria (Figura 17). Loteamentos surgiram, como o Vale das Araucárias, Residencial Vale do Arvoredo, Royal Golf Residences, Bela Manhã, e outros, todos de alto padrão (Figura 18). Pode-se dizer, que o shopping "atuou como agente modificador da

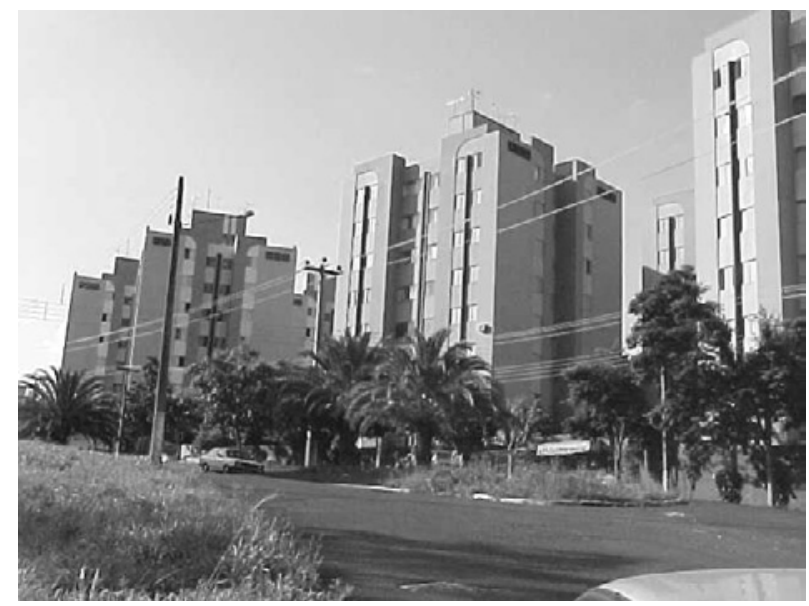

Fonte: Foto do autor

Figura 17 - Quinta da Boa Vista Apartamento Residenciais

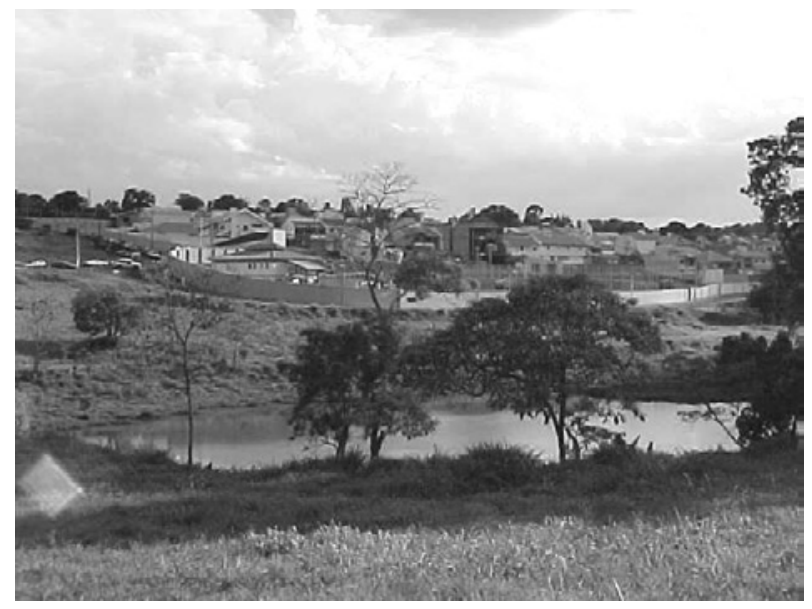

Fonte: foto do autor, set. 2000

Figura 18 - O Vale das Araucárias - condomínio horizontal.

ocupação do solo no seu entorno, gerando tanto um processo de incorporação de novas regiões de uso residencial horizontal, quanto um processo crescente de substituição do uso residencial horizontal pelo vertical" (GRASSIOTTO, 2000). A implantação do shopping Catuaí, funcionou como um importante instrumento de descentralização urbana. Novas áreas foram incorporadas no processo de desenvolvimento da cidade. "A atração negocial gerada pelo centro comercial, desencadeou ainda um processo de crescimento da atividade comercial no seu entorno imediato, determinando a formação de novos pólos de comércio e serviços" (GRASSIOTTO, 2000). Todos esses empreendi-mentos gerados, acabaram se constituindo num "upgrade" para a região, cuja estrutura urbana foi remodelada e implementada com novos equipamentos urbanos. Hoje pode-se afirmar que o shopping Catuaí, construiu uma localização. Sua interferência se deu através: da valorização do solo das imediações; alteração do seu uso; aumento da densidade populacional; maior congestionamento de tráfego; e recuperação de áreas deterioradas. Podese ainda dizer, que apesar de ser causa do "upgrade" nas regiões de seu entorno, foi também causa do aumento da velocidade da decadência do centro tradicional, provocando mudanças na hierarquia tradicional dos centros de comércio. 
A instalação do shopping alterou o sistema varejista da cidade e sua economia, como um todo. Além de ofertar mais empregos, modificou sua imagem, ofereceu novos equipamentos aos habitantes, como salas de cinema e grandes áreas de lazer. Transformou-se numa nova centralidade, modificando sensivelmente os hábitos sociais e culturais dos habitantes. Com tudo isso, favoreceu o aumento da arrecadação, provocando o interesse de investimento no setor pela prefeitura.

O zoneamento da cidade sofreu intensas mudanças em decorrência da instalação do shopping Catuaí e a partir de 1998 a cidade passou a contar com seu primeiro Plano Diretor, que incorporou no zoneamento, todas as alterações provocadas pelo shopping em sua estrutura urbana.

O shopping Catuaí aproveitando-se de seu caráter dinâmico, vem agregando cada vez mais espaços interessantes em suas dependências. Hoje, pode-se dizer que transformou-se na principal opção de compras e lazer do londrinense, é um ponto de encontro, um símbolo, um marco de referência cultural, capaz de atender plenamente às novas aspirações do usuário consumidor.

\section{Shopping Center Royal Plaza e a Revitalização do Centro Tradicional}

O shopping Royal Plaza ${ }^{16}$ possui $19.500 \mathrm{~m}^{2}$ de área construída (Figura 19, 20). Regional, vertical, sem âncoras departamentais, oferece: 400 vagas de estacionamento; ambiente climatizado; 4 elevadores (um panorâmico); 6 escadas rolantes; 169 lojas; 15 quiosques; 2 salas de cinema; praça de alimentação; diversões eletrônicas; praça de eventos e lazer; 1 cursinho.

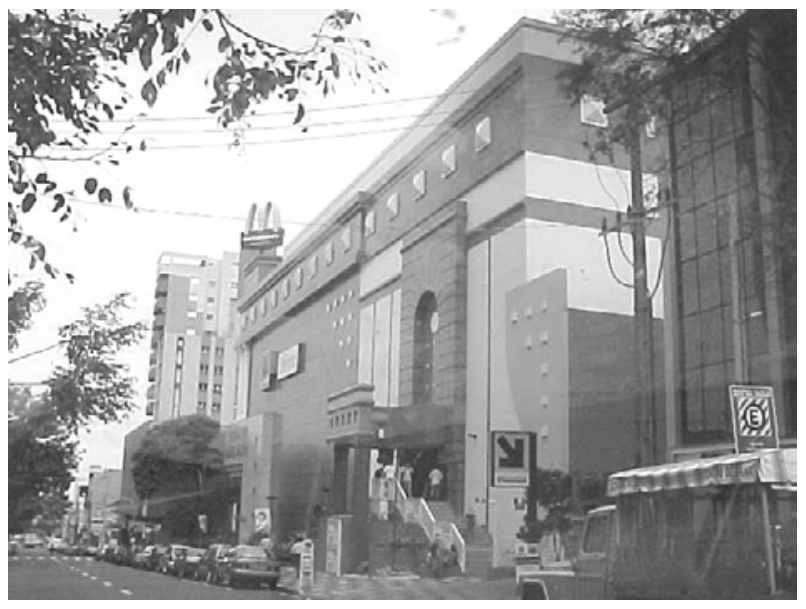

Fonte: foto do autor, jul. 2000

Figura 19 - Shopping Royal Plaza- Fachada rua Maranhão.

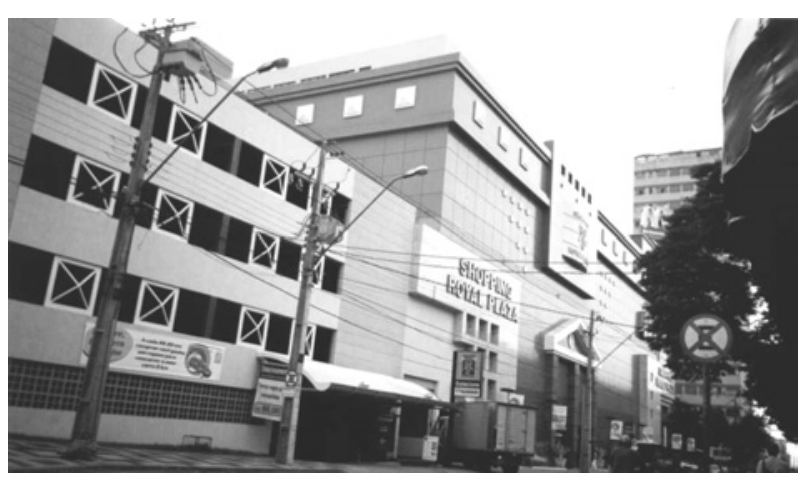

Fonte: foto do autor, jul. 2000

Figura 20 - Shopping Royal Plaza - Fachada rua Mato Grosso.

Com história diversa do Catuaí, o Royal Plaza não foi construído como shopping tradicional. Um grupo de investidores se uniu com o intuito de auferir lucros com a venda das diversas unidades, e acabou sendo construído pelo sistema de condomínio a preço de custo ${ }^{17}$. O empreendimento foi um sucesso de vendas, com a comercialização de todos os espaços disponíveis em apenas 24 horas.

\footnotetext{
${ }^{16}$ Projeto do arquiteto José Carlos Mendes Cardoso, de Maringá, teve como principal empreendedor a Viação Garcia Ltda., também dona do terreno, e a Granacon Construções Civis, como construtora contratada por administração para execução da obra, também de Maringá. O processo de vendas foi realizado pela Schietti \& Medeiros de Londrina em parceria com a Eldorado, responsáveis também pela definição do mix de lojas, mais adequado para vendas.

17 Envolve a execução de uma determinada obra por administração por meio da contratação de uma construtora. No primeiro momento é formado um grupo com interesse comum na instalação de um empreendimento. Juridicamente constituído, esse grupo dá seqüência ao trabalho com a contratação de uma construtora. Às vezes, uma empresa imobiliária se propõe a formar o grupo que irá constituir o condomínio, através de um processo de adesão com um objetivo pre-estabelecido (caso do Shopping Royal Plaza).
} 
O shopping center Royal Plaza, foi implantado na esquina das ruas Maranhão com Mato Grosso, local onde nasceu há 42 anos a empresa Viação Garcia. Ali se localizavam suas primeiras garagens, e funcionou a loja da empresa até a realização do empreendimento. Situado portanto, no coração da cidade, próximo ao calçadão da Av. Paraná, beneficiou-se de uma estrutura urbana pronta e em funcionamento, com sistema viário consolidado, no centro tradicional da cidade (Figura 4). Nas suas imediações encontram-se a Catedral, o Correio, a Biblioteca Pública, o Museu Histórico, o Museu de Arte Moderna, as Lojas Americanas e o Terminal de Transporte Coletivo, fator este, que garante um mercado consumidor em potencial. Pelo calçadão da Av. Paraná, circulam por dia 40.000 pessoas aproximadamente e 9.000 veículos. O shopping, desse modo, nasceu com o ponto já feito, sendo sua localização a maior âncora. Privilegia moradores e trabalhadores do centro, dada a presença de inúmeros edifícios residenciais, assim como de numerosas agências bancárias, lojas diversas e prestadores de serviços. "O fato de ter sido construído na área mais antiga e tradicional do comércio londrinense também fortalece o novo e moderno conceito empregado nos grandes centros de compras: o shopping city" (CARDOSO, 1999, p.6 ).

Ainda em processo de consolidação, o Royal Plaza já mostra sua influência como revitalizador da área central da cidade. Os comerciantes se adaptam gradativamente ao progresso trazido pelo empreendimento, que colocou à disposição do usuário, além de lojas, uma grande área de lazer e entretenimento, permanecendo a facilidade das compras à pé. $\mathrm{O}$ próprio shopping é uma âncora, um estímulo aos hábitos de consumo no centro, principalmente com a motivação da liberação do horário comercial. Resgata ainda um pouco da origem da cidade. O londrinense pode conhecer parcela de sua história, com a área central voltando à evidência através do edifício do shopping, valorizando a importância do local. A sua instalação, consistiu num instrumento de "upgrade" da região. As ruas do seu entorno e os estabelecimentos aí existentes, passaram a se preocupar com a melhoria da aparência e da própria imagem. Ao mesmo tempo, já se percebe o aparecimento de um comércio mais sofisticado nos arredores, mostrando um processo interativo entre comércio de rua e shopping, que certamente redundará em intensa melhoria ambiental.

A localização do shopping, sua maior âncora, é também causa de sua maior deficiência: a escassez de vagas de estacionamento. O terreno, pequeno e de alto valor, não favoreceu a construção de um maior número de vagas, pois isso inviabilizaria o empreendimento. Ao mesmo tempo, a situação privilegiada convive com a precariedade de vagas das ruas centrais e circunvizinhas, agravando ainda mais o problema.

Lembrando os grandes magazines europeus, em sua verticalidade e luxo, o shopping Royal Plaza mostra sua presença, em terreno valorizado, e sua escala monumental transforma-o num marco, num diferencial da região em que se localiza: edifício retangular totalmente fechado e ornamentado, um referencial; caixote com segurança, climatizado, capaz de neutralizar o ruído forte do centro da cidade: sem integração interior/exterior, o usuário ao adentrar o recinto é atraído pelos efeitos cenográficos da arquitetura de interiores.

\section{Tendências e Considerações Finais}

Ao final deste texto, pode-se tecer algumas considerações. Após uma pequena introdução acerca dos modos de se olhar as cidades, seu desenvolvimento e crescimento, mostrou-se a importância da atividade comercial aliada ao social, para o homem desde os primeiros tempos, assim como se relatou a evolução do comércio varejista até o aparecimento do shopping center. Procurouse caracterizar o edifício do shopping center, e colocar as condições de seu surgimento, tendo em vista uma avaliação correta da complexidade atual dos centros comerciais varejistas. Depois disso o foco passou a ser Londrina, com a abordagem de aspectos de sua origem e desenvolvimento. Apresentou-se a evolução de seus espaços comerciais, até o aparecimento dos shopping centers, sempre em contraponto, com sua expansão residencial e crescimento urbano. Finalmente, aspectos da implementação dos dois shopping centers principais 
da cidade, o Catuaí e o Royal Plaza foram descritos, com o intuito de se compreender a influência de cada um no crescimento, desenvolvimento e seu papel na atual configuração urbana da cidade.

Pode-se dizer que os dois empreendimentos citados, são de ordem diversa, mas complementares. O Catuaí, super-regional, horizontal, seguindo os moldes americanos em seus mais variados aspectos é fruto de pesquisa e, foi instalado na periferia, em terreno rigorosamente escolhido, e profissionalmente planejado, visando a atingir um determinado público alvo. Com todas as facilidades de acesso, amplo estacionamento, com diversas opções de compra e lazer, conforto e segurança, tornou-se um centro atrativo, uma cidade em miniatura, reproduzindo num espaço privado, os inúmeros equipamentos urbanos de um espaço público, que o centro tradicional não é mais capaz de oferecer. Dessa maneira, criou sua própria localização, sendo instrumento de descentralização urbana, causando intensa transformação na região de seu entorno, provocando alteração de usos, e principalmente se constituindo num fator de aceleração da decadência do centro tradicional. Além das opções de compra, ele oferece a âncora do lazer e entretenimento de modo que, hoje se constitui num ponto de encontro de jovens, adolescentes e inclusive casais da sociedade. Tendo completado 10 anos de funcionamento, é um shopping consolidado, tendo se transformado numa referência cultural, social, e num marco arquitetônico da cidade.

O Royal Plaza, com pouco mais de dois anos de funcionamento, está em período de consolidação, foi implantado no coração da cidade, seu centro histórico. Com caráter regional, vertical, e sem âncoras, foi construído pelo sistema condomínio a preço de custo, onde o lojista é dono, diferentemente de um shopping convencional. Erguido em terreno exíguo, de alto valor, com carência de vagas para estacionamento, mostra na sua verticalidade, a similaridade com os grandes magazines europeus do século XIX, e com os novos centros comerciais instalados nos centros tradicionais das cidades, com o intuito de revitalização de áreas deterioradas. O Shopping Royal Plaza, também veio para revigorar o centro de Londrina, e, nesse sentido, apresenta-se como um edifício marcante, referencial, tendo já provocado um "upgrade" em seus arredores. Fechado e isolado do exterior, constitui-se também numa cidade em miniatura. Seu usuário é diferente do usuário do Catuaí. É o morador da redondeza, mas principalmente o trabalhador do centro, o estudante, que vai passear e tomar refeições em suas dependências. Diferentemente do Catuaí, que tem seu maior movimento nos finais de semana, o seu maior fluxo de pessoas acontece durante a semana.

Pode-se dizer, que os shopping centers são um universo em constante mutação. Segundo alguns estudiosos, constituem "ilhas pós-modernas, enclaves de prosperidade, oásis urbanos” (RIMKUS, 1998).

Independentemente das características diversas de cada um, os shoppings centers Catuaí e Royal Plaza, além de acompanhar a dinâmica das transformações do contexto urbano, econômico e cultural, são instrumentos de sua alteração, e nesse sentido os dois exemplares de Londrina têm confirmado essa condição.

Em maio de 2001, o último Spring Convention em Las Vegas sinalizou para o novo rumo que a indústria de shopping centers está tomando, o de empreendimentos voltados ao turismo. Aliado a isso estão ocorrendo revitalizações de inúmeros centros urbanos, com a participação ativa nesses movimentos, da indústria de shopping centers.

O shopping center possui enorme potencial como instrumento de transformação social, pois tem a capacidade de criar uma onda desenvolvimentista e de progresso ao seu redor. Provoca expansão imobiliária no entorno (residencial, empresarial, comercial e de serviços), grandes melhoramentos de infra-estrutura urbana (passarelas, viadutos, calçamentos, sinalizações, revitalização de praças, parques públicos e áreas centrais), valorização de terrenos e imóveis e consequentemente passa a atrair novos investimentos na região. Pode-se observar estas questões na cidade de Londrina, e em São Paulo, só para citar alguns, tem-se o West Plaza na Barra Funda e o Jardim Sul no Morumbi, que desencadearam grandes alterações urbanas. O shopping Tatuapé é um exemplo de associação com o metrô bem sucedida. 
E a mais nova tendência internacional que também passa a acontecer no solo brasileiro (e em Londrina) é agregar atividades complementares na vizinhança do shopping. É o complexo multiuso, o que há de mais moderno em termos de proposta arquitetônica de shopping centers. Significa a inclusão de hotéis, centros de convenções, centros médicos, escolas, torres de escritórios, casa de shows, como prática comum para geração de público constante em um mesmo local. As atividades anexas acabam funcionando como superâncoras para o shopping center (Figura 21, 22).

Alguns empreendimentos multiuso estão em andamento: o Brascan Open Mall e o Brascan Century Plaza em Itaim Bibi, em São Paulo, um shopping aliado a três torres, sendo a maior (30 andares) um apart-hotel, e as duas outras (24 andares), para ocupação comercial, prevendo-se um fluxo diário de 20.000 pessoas para freqüentar o shopping; o Frei Caneca Shopping \& Convention Center (S. P.) teve sua primeira fase inaugurada em maio de 2001, prevendo centro de convenções, gourmet center, complexo multiplex de cinemas, escola profissionalizante, teatro, hotel, etc. Como exemplo de expansão, o Barrashopping no Rio de Janeiro, que apesar de já ter se expandido quatro vezes, desenvolve no momento a construção do Complexo Empresarial Barrashopping, composto de onze edificações, abrigando, entre outras instituições, a Universidade Estácio de Sá (7.000 alunos), as instalações da Shell, da Amil, um centro de convenções, um shopping de conveniência, centro médico, 32 clínicas especializadas, e ainda a previsão de um hospital. A inauguração está prevista para este ano (2002), e os empreendedores esperam dobrar o fluxo de pessoas no shopping chegando a 70.000 por dia (ASSOCIAÇÃO BRASILEIRA DE SHOPPING CENTERS, 2001b). São todos mega empreendimentos que muito interferem no urbano, e, nesse caso, representam praticamente a construção de um bairro, com papel importantíssimo na sustentabilidade do desenvolvimento urbano de um modo geral.
O fato é que os shopping centers têm passado por um constante processo de transformações: no princípio pareciam ruas, funcionando ao ar livre, com supermercados; depois galerias fechadas com ar condicionado e lojas de departamentos; em seguida lojas de variedades; e no início dos anos 70, a alimentação e o entretenimento foram introduzidos como âncora. Também na década de 70, o shopping center passou a ter função social, que cada vez se intensifica mais. Nos anos 90, a indústria de shopping centers mostra-se amadurecida, e o conceito de compras com lazer chegou para ficar. Surgem em profusão os parques temáticos, as áreas verdes aliadas aos shoppings, os festival centers, os complexos multiusos, e a freqüência a esses ambientes, atualmente, faz parte da cultura da sociedade globalizada (ASSOCIAÇÃO BRASILEIRA DE SHOPPING CENTERS, 2001a).

O shoppings são parte integrante do cotidiano do cidadão brasileiro, e são impulsionadores da economia do país. No Brasil são 230, com 217 em operação e 23 em construção, que respondem por $15 \%$ do faturamento do varejo nacional (excluído o automotivo), gerando 400.000 empregos diretos. O interior já abriga $41 \%$ do total de shoppings, mas são 40 empreendimentos somente na cidade de São Paulo, que está entre as primeiras colocadas no ranking mundial em número de shopping centers (ASSOCIAÇÃO BRASILEIRA DE SHOPPING CENTERS, 2002).

\section{Referências}

ASSOCIAÇÃO BRASILEIRA DE SHOPPING CENTERS (ABRASCE). Urbanismo:reação em cadeia. Revista Shopping Centers. set. 2001a. Disponível em: http:// www.abrasce.com.br/REVISTAS/2001/revset/ urbanismo.htm. Acesso em: $07 \mathrm{fev} .2002$.

Multiuso - mil e uma atividades. Revista Shopping Centers. set. 2001b. Disponível em: http:// www.abrasce.com.br/REVISTAS/2001/revset/ multiuso.htm. Acesso em: 07 fev. 2002.

Apresentação e histórico da indústria de

shoppings no Brasil. Disponível em: http:// www.abrasce.com.br/aprehist.htm. Acesso em: 7 fev. 2002. 
BERNARDES, L. M. C. O problema das frentes pioneiras no estado do Paraná. Revista Brasileira de Geografia, Rio de Janeiro, v.15, n.3, p.3-49, jul./set. 1953.

BURKE, P. A escola dos annales (1929-1989): a revolução francesa da historiografia. São Paulo: Fundação Editora da UNESP, 1991.

CARDOSO, S. Londrina ganha hoje seu mais novo shopping. Folha de Londrina, Londrina, 30 nov. 1999. Folha Especial, $24 \mathrm{p}$.

CATUAÍ SHOPPING CENTER. Conheça o Catuaí Shopping Center. Disponíl em: <http://www.catuaishopping.com.br/ shopping.asp.> Acesso em: 2000.

O COM-TOUR e sua pequena história. Vida Ativa. Londrina, 2000.

FRANÇA, A. A marcha do café e as frentes pioneiras. Rio de Janeiro: Conselho Nacional de Geografia, 1960.

GRASSIOTTO, M. L.F. Espaços comerciais: a arquitetura em dois shopping centers de Londrina. 2000. Dissertação (Mestrado em Estruturas Ambientais Urbanas) Faculdade de Arquitetura e Urbanismo, Universidade de São Paulo, São Paulo.

Evolução urbana de Londrina. 1980. Trabalho de Conclusão de Curso (Graduação em Geografia) Departamento de Geografia, Universidade Estadual de Londrina, Londrina, 1980.

Evolução urbana de Londrina. 1975. Trabalho Acadêmico (Graduação em Geografia) - Departamento de Geografia, Universidade Estadual de Londrina, Londrina.

GUNN, P. M. Espaço, estado e território: contribuição à análise crítica da organização social em São Paulo e no Brasil. 1985b. Tese (Doutorado) - Faculdade de Arquitetura e Urbanismo, Universidade de São Paulo, São Paulo.

As políticas e a realidade do assentamento industrial em São Paulo. São Paulo: Livraria Nobel, 1985a. (Sinopses, 8)

Os processos de planejamento e de projeto urbano: AUT 5.800. São Paulo: FAU/USP, 2002 (Notas de aula.- Programa de Doutorado)

HIRSCHFELDT, R. V. Shopping center : o templo do consumo. 1986. Trabalho de Conclusão de Curso (Economia)- Faculdade Cândido Mendes, Rio de Janeiro.

LIMA FILHO, A. O. Shopping centers - E.U.A. vs: Brasil uma análise mercadológica comparativa. Rio de Janeiro: Fundação Getúlio Vargas, 1971.

LONDRINA. Prefeitura Municipal. Projeto de Serviços e Informações Utilitárias. Londrina em dados. Disponível em: <http://www.londrina.pr.gov.br/utilidadepublica/ informacoes.php3.> Acesso em: 2001
MASANO, T. F. Os Shopping centers e suas relações físico-territoriais e sócio-negociais no município de São Paulo. 1993. Tese (Doutorado) - Faculdade de Arquitetura e Urbanismo, Universidade de São Paulo, São Paulo.

RIFKIN, J. A era do acesso. a transição de mercados convencionais para networks e o nascimento de uma nova economia. São Paulo: Makron Books, 2001.

RIMKUS, C. M. F. Shopping centers: expressão arquitetônica da cultura capitalista de consumo. 1998. Tese (Doutorado) - Faculdade de Arquitetura e Urbanismo, Universidade de São Paulo, São Paulo.

SCHWARTZ, W. Poder emergente no sertão. Londrina: Associação Comercial e Industrial de Londrina: Midiograf, 1997.

SHIMBA, O. Y.; UREN, F. H. R. Londrina cidade cenário. Londrina: Midiograf, 1999.

SUDJIC, D. Third Megacities Lecture. nov. 1999. Disponível em: <http://www.megacities.nl/ lecture sudjic.htm>. Acesso em: 2000

VARGAS, H. C. Comércio: localização estratégica ou estratégia da localização? 1993. Tese. (Doutorado) Faculdade de Arquitetura e Urbanismo, Universidade de São Paulo, São Paulo.

A lógica do espaço terciário: o lugar a arquitetura e a imagem do comércio. 2000. Tese (Livre Docência) - Faculdade de Arquitetura e Urbanismo, Universidade de São Paulo, São Paulo.

VILLAÇA, F. Espaço intra-urbano no Brasil. São Paulo: Studio Nobel, 1998.

\section{Agradecimentos}

Ao empreendedor do Catuaí Shopping Center eng. Alfredo Khouri, ao arquiteto Carlos Dominguez, à equipe administrativa representados por: Elcy Oliveira (diretora administrativa e financeira); Odair Daroque (superintendente) e Roserval Rocha (engenheiro).

À eng. Stela Maris Pelegrino e ao arquiteto José Carlos M. Cardoso do Shopping Royal Plaza.

Aos alunos colaboradores: Maria Fernanda Sakita; Patricia Mafra; Thais Manfrin; Thalita Rubio; Allan Tomio Horikawa; Alexandro Bini; Marcio R. de Araújo e Marco Aurélio Carlotto. 